\title{
Biomass production and essential oil content and composition in basil hydroponic systems using treated domestic effluents
}

\section{Producción de biomasa, contenido y composición del aceite esencial de albahaca en sistemas hidropónicos utilizando efluentes domésticos tratados}

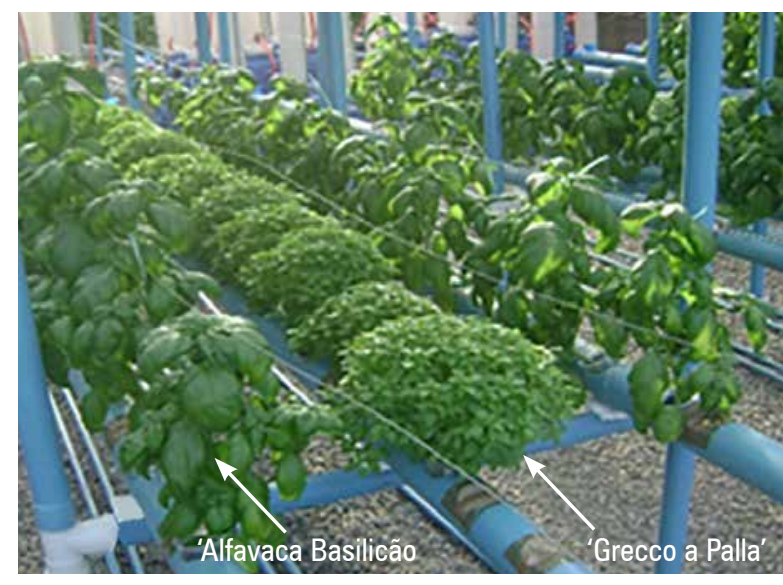

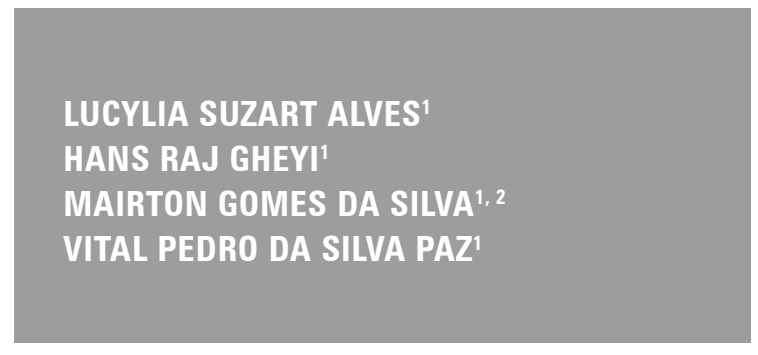

Basil plants grown under hydroponic conditions.

Photo: L.S. Alves

\begin{abstract}
Reusing domestic wastewater is an alternative for irrigated agriculture, helping to decrease pressure on good quality water. This study aimed to evaluate the biomass production and essential oil content and composition in the basil genotypes 'Alfavaca Basilicão' and 'Grecco a Palla' with different plant spacing in hydroponic systems. Two experiments were carried out between March and May (Experiment I) and July and September of 2015 (Experiment II) in a completely randomized design with four replicates in a $2 \times 3$ factorial arrangement. In Experiment I, two hydroponic systems (Laminar Nutrient Flow Technique - NFT and Deep Nutrient Flow Technique - DFT) and three plant spacings in hydroponic channels $(0.20,0.30$, and $0.40 \mathrm{~m})$ were evaluated. In Experiment II in the DFT hydroponic system, two types of water (tap water and treated domestic effluents) and three nutrient solution recirculation intervals (at intervals of 2, 4, and $6 \mathrm{~h}$ ) were evaluated. In general, the dry biomass per plant, oil content and oil yield of the two basil genotypes were not influenced by the hydroponic systems, plant spacing, or water type. In Experiment II, the increase between the recirculation intervals ( 4 or $6 \mathrm{~h}$ ) negatively affected genotype 'Grecco a Palla'. Linalool was the major constituent in the essential oil of the two basil genotypes, ranging from 47.00 to $70.10 \%$ (Experiment I) and from 59.47 to $63.64 \%$ (Experiment II) in genotype 'Alfavaca Basilicão'; in genotype 'Grecco a Palla', it ranged from 10.19 to $43.03 \%$ (Experiment I) and from 19.94 to $53.37 \%$ (Experiment II).
\end{abstract}

Additional keywords: Ocimum basilicum; Ocimum minimum; cultivation without soil; water scarcity.

Federal University of Recôncavo of Bahia, Soil and Water Engineering Nucleus, Cruz das Almas (Brazil). ORCID Alves, L.S.: 0000-0003-1881-4881; ORCID Gheyi, H.R.: 0000-0002-1066-0315; ORCID Silva, M.G.: 0000-0003-2140-201X; ORCID Paz, V.P.S.: 0000-0002-8034-668X

2 Corresponding author. mairtong@hotmail.com 


\section{RESUMEN}

La reutilización de aguas residuales domésticas es una alternativa para la agricultura de riego, contribuyendo así a disminuir la presión sobre el agua de consumo humano. En este contexto, el estudio tuvo como objetivo evaluar la producción de biomasa, el contenido y la composición de aceite esencial de los genotipos de albahaca 'Alfavaca Basilicão' y 'Grecco a Palla' bajo diferentes distancias de plantación en sistemas hidropónicos. Se realizaron dos experimentos, entre marzo y mayo (Experimento I) y julio y septiembre de 2015 (Experimento II) en un diseño completamente al azar con cuatro repeticiones, en un arreglo factorial $2 \times 3$. En el Experimento I se evaluaron dos sistemas hidropónicos (Técnica de Flujo Laminar de Nutrientes - NFT y Técnica de Flujo Profundo - DFT) y tres distancias de plantas en los canales hidropónicos $(0,20 ; 0,30$ y 0,40 m). Mientras que en el Experimento II se utilizó solo en el sistema hidropónico DFT y se evaluaron dos tipos de agua (red de abastecimiento de agua tratada y efluentes domésticos tratados) y tres intervalos de recirculación de soluciones nutritivas (a intervalos de 2, 4 y 6 h). En general, la biomasa seca por planta, el contenido de aceite y el rendimiento de aceite de los dos genotipos de albahaca no fueron influenciados por los sistemas hidropónicos, el espaciamiento de las plantas o el tipo de agua. En el Experimento II, el aumento entre los intervalos de recirculación (4 o 6 h) afectó negativamente al genotipo 'Grecco a Palla'. El linalool fue el componente principal en el aceite esencial de los dos genotipos de albahaca, variando del 47,00 al 70,10\% (Experimento I) y del 59,47 al 63,64\% (Experimento II) en el genotipo 'Alfavaca Basilicão'; en el genotipo 'Grecco a Palla' osciló entre 10,19 y 43,03\% (Experimento I) y entre 19,94 y 53,37\% (Experimento II).

Palabras clave adicionales: Ocimum basilicum; Ocimum minimum; cultivo sin suelo; escasez de agua.

Received: 23-03-2020 Accepted: 26-01-2021 Published: 24-02-2021

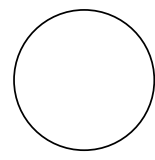

INTRODUCTION

The current challenge in tropical agriculture is increasing crop production with water scarcity, in terms of quality and quantity (Fuentes-Castañeda et al., 2016). Low quality water sources have been sought for irrigation, including the use of treated domestic effluents (Cifuentes-Torres et al., 2020; Egbuikwem et al., 2020).

Appropriate systems for irrigation with treated domestic wastewater are needed to reduce risks of human and environmental contamination. An environmentally and sanitarily viable solution for the disposal of these waters is hydroponic cultivation. In hydroponics, according to Cuba et al. (2015), there is no direct contamination of the aerial part of the plants because the effluent only has contact with the roots.

The NFT (Nutrient Film Technique) system is the most commonly used; however, non-availability of electricity in some areas or secure source of power supply circulation of nutrient solution in the hydroponic channels (Silva et al., 2016), even for short time intervals, may lead to total loss of production. For this reason, the DFT (Deep Nutrient Flow Technique) system has emerged, in which a film of nutrient solution is kept in the tube during the cultivation period, making it possible to meet the water needs of plants in case there is a power interruption (Silva et al., 2016). Yet another advantage of this system is energy savings because the nutrient solution recirculation interval does not need to be as short as in the NFT system.

Studies on the DFT system adapted in PVC tubes have been conducted mainly with vegetables, such as coriander (Santos Júnior et al., 2015; Silva et al., 2018; Silva et al., 2020a), lettuce (Cova et al., 2017) and chicory (Silva et al., 2020b). According to Bione et al. (2014), in hydroponic cultivation, it is easier to diversify crops, and medicinal/condiment plants such as basil have more space.

Basil is used in cooking as a condiment, especially its fresh leaves. In addition, basil is used to extract essential oil, which is rich in phenolic compounds, with multiple uses in food, cosmetic, perfume and pharmaceutical industries (Heidari, 2012), and linalool is one of the most appreciated components of the essential oil (Veloso et al., 2014).

Basil has shown better yield in cultivation systems without soil (hydroponics) than in conventional systems (Saha et al., 2016). Therefore, it has been grown 
under different hydroponic conditions. Walters and Currey (2015) and Santos et al. (2019) found no significant differences for growth variables and production of basil under cultivation in the hydroponic systems NFT and DFT. The use of marginal quality water, such as brackish water, increased the yield of essential oil in the basil genotypes 'Grecco a Palla' (Gondim Filho et al., 2018) and 'Gennaro de Menta' (Azevedo Neto et al., 2019; Silva et al., 2019). In addition, the use of treated domestic effluents proved to be viable for the cultivation of this crop (Alves et al., 2019; Gonçalves et al., 2019) in DFT hydroponic system in tubes.

The objective of this study was to evaluate the biomass production and essential oil content and composition of two basil genotypes: 'Alfavaca Basilicão' (Ocimum basilicum L.) and 'Grecco a Palla' (Ocimum minimum L.), in hydroponic systems with different plant spacing using treated domestic effluents.

\section{MATERIALS AND METHODS}

\section{Cultivation conditions and study location}

Two experiments with basil were carried out in a greenhouse (East-West orientation), from March to May (Experiment I) and from July to September (Experiment II) in 2015 in the experimental area of the Post Graduate Program in Agricultural Engineering at the Soil and Water Engineering Nucleus at the Federal University of Recôncavo of Bahia (UFRB), located in the municipality of Cruz das Almas, Bahia State, Brazil (12 $40^{\prime} 19^{\prime \prime} \mathrm{S}, 39^{\circ} 06^{\prime} 23^{\prime \prime} \mathrm{W}$, and at an elevation of $220 \mathrm{~m}$ a.s.1.).

\section{Experiment design and treatments}

In both experiments, the basil genotypes 'Alfavaca Basilicão' (Ocimum basilicum L.) and 'Grecco a Palla'
(Ocimum minimum L.) were used and analyzed individually. The experiments were carried out in a completely randomized design with four replicates in a $2 \times 3$ factorial arrangement. Only treated domestic effluents were used in Experiment I; two hydroponic systems (NFT and DFT adapted in PVC tubes) and three plant spacings in the hydroponic channels $(0.20,0.30$, and $0.40 \mathrm{~m})$ were evaluated. In Experiment II, the DFT hydroponic system, two types of water (tap water and treated domestic effluents) and three nutrient solution recirculation intervals $(2,4$, and $6 \mathrm{~h})$ were evaluated. Hydroponic cultivation is a closed system in which the nutrient solution is recirculated. The NFT hydroponic system is characterized by frequent circulation of the nutrient solution, generally with short intervals of $15 \mathrm{~min}$. The DFT system has a layer of nutrient solution that remains in constant contact with the roots, as such, the plants do not undergo any water restriction, which means the interval time between the circulation of the nutrient solution can be extended, as has been shown by various authors (Silva et al., 2016; Silva et al., 2018; Santos et al., 2019; Silva et al., 2020a).

The treated domestic effluents came from the sewage treatment unit of the Bahia State Water and Sanitation Company (EMBASA), located in the municipality of Muritiba, Bahia State, Brazil. To avoid large variations resulting from seasonality, a sufficient volume was collected and stored to conduct the experiments. The domestic sewage was treated with a grid and box of sand, removing all solid material, and then placed in a reactor and pond, where about $90 \%$ of the organic matter was digested, and pathogens such as viruses and bacteria were eliminated. The characteristics of treated domestic effluents and tap water are shown in table 1.

The water was used to prepare the nutrient solution of Furlani et al. (1999) (Tab. 2) and to replenish the volume consumed by the basil plants.

Table 1. Physio-chemical characterization of treated domestic effluents (TDE) and tap water (TW).

\begin{tabular}{|c|c|c|c|c|c|c|c|c|c|c|c|c|c|}
\hline \multirow{2}{*}{ Water } & \multirow{2}{*}{$\mathrm{pH}$} & EC & $P$ & K & N & $\mathrm{Na}$ & $\mathrm{Ca}$ & Mg & $\mathrm{Cl}$ & $\mathrm{SO}_{4}$ & $\mathrm{CO}_{3}$ & $\mathrm{HCO}_{3}$ & SAR \\
\hline & & $\left(\mathrm{dS} \mathrm{m}^{-1}\right)$ & \multicolumn{10}{|c|}{$\left(\mathrm{mg} \mathrm{L}^{-1}\right)$} & $\left(\mathrm{mmol} \mathrm{L}^{-1}\right)^{0.5}$ \\
\hline TDE & 7.16 & 1.00 & 0.05 & 29.32 & 21.85 & 138.00 & 15.00 & 18.96 & 175.83 & A & $P$ & 238.51 & 5.55 \\
\hline TW & 6.41 & 0.25 & - & 6.63 & - & 39.79 & 20.40 & 21.12 & 66.29 & $P$ & A & 25.01 & 2.93 \\
\hline
\end{tabular}

Analyzed in Laboratory of Sanitary Engineering of Federal University of Campina Grande, Paraíba State, Brazil.

A - Absent; P - Present. 
Table 2. Composition of standard nutrient solution of Furlani et al. (1999) utilized in the study.

\begin{tabular}{|l|c|c|c|c|c|c|c|c|c|c|c|c|c|c|c|}
\hline \multirow{2}{*}{ Fertilizers } & $\mathrm{Conc}$ & $\mathrm{NH}_{4}$ & $\mathrm{NO}_{3}$ & $\mathrm{P}$ & $\mathrm{K}$ & $\mathrm{Ca}$ & $\mathrm{Mg}$ & $\mathrm{S}$ & $\mathrm{B}$ & $\mathrm{Cu}$ & $\mathrm{Fe}$ & $\mathrm{Mn}$ & $\mathrm{Mo}$ & $\mathrm{Zn}$ \\
\hline & \multicolumn{7}{|c|}{$\mathrm{mg} \mathrm{L}^{-1}$} & & & \\
\hline Calcium nitrate dihydrate & 750 & 7.5 & 108.75 & & & 142.5 & & & & & & & & \\
\hline Potassium nitrate & 500 & & 65 & & 182.5 & & & & & & & & & \\
\hline Mono ammonium phosphate & 150 & 16.5 & & 39 & & & & & & & & & & \\
\hline Magnesium sulphate & 400 & & & & & & 40 & 52 & & & & & & \\
\hline Copper sulphate & 0.15 & & & & & & & & & 0.02 & & & & \\
\hline Zinc sulphate & 0.30 & & & & & & & & & & & & & 0.07 \\
\hline Manganese sulphate & 1.50 & & & & & & & & & & & 0.39 & \\
\hline Boric acid & 1.80 & & & & & & & & 0.31 & & & & & \\
\hline Sodium molybedate & 0.15 & & & & & & & & & & & & 0.06 & \\
\hline Tenso-Fe (FeEDDHMA 6\%) & 35 & & & & & & & & & & 2.08 & & & \\
\hline Concentration (Conc) & & 24 & 173.75 & 39 & 182.5 & 142.5 & 40 & 52 & 0.31 & 0.02 & 2.08 & 0.39 & 0.06 & 0.07 \\
\hline
\end{tabular}

\section{Experiment structure}

In Experiment I, both hydroponic systems had channels made of PVC tubes (6-m length and $0.075 \mathrm{~m}$ in diameter). The plants were spaced apart in the channels according to the corresponding spacing (0.20, 0.30 , or $0.40 \mathrm{~m}$ ), grown in circular holes with a 0.05 $\mathrm{m}$ diameter. The hydroponic channels were installed with zero and $3 \%$ slopes in the DFT (Fig. 1A) and NFT (Fig. 1B) systems, respectively. In Experiment II, the same structure was used; however, only the DFT hydroponic system was tested with a single plant spacing $(0.20 \mathrm{~m})$ in the channels. More details of the experiment structure can be seen in Alves et al. (2019).

\section{Seedling production}

In Experiment I, basil seeds (ISLA Sementes ${ }^{\circledR}$, Porto Alegre, Brazil) were sown on 6 March 2015 in 110$\mathrm{mL}$ plastic cups containing coconut fiber substrate (home fabrication). Three seeds were sown per cup (individually per genotype) and covered with a thin layer of vermiculite. The bottoms of the cups were cut for root growth. The seedlings were manually irrigated until 15 days after sowing (DAS) using tap water, with an electrical conductivity (EC) of 0.25 $\mathrm{dS} \mathrm{m}^{-1}$. Afterwards, thinning was carried out, leaving one seedling per cup, and the irrigation was performed with the nutrient solution of Furlani et al. (1999) at 50\% concentration for $15 \mathrm{~d}$.
For Experiment II, basil seeds were sown on 27 July 2015 on $2 \times 2 \times 2 \mathrm{~cm}$ phenolic foam (Oasis ${ }^{\circledR}$ Produtos Florais, Holambra, Brazil), planting one seed per cell, and covered with vermiculite. After germination, seedlings were irrigated daily with EC of $0.25 \mathrm{dS} \mathrm{m}^{-1}$ water until 15 DAS. After this period, the seedlings were transferred to a nursery (NFT system), where they received a nutrient solution (Furlani et al., 1999) at $50 \%$ concentration for $15 \mathrm{~d}$. The irrigation in the nursery were controlled with an analog timer at intermittent intervals of $15 \mathrm{~min}$, from 06:00 to 18:00 h. From 18:00 to $06: 00 \mathrm{~h}$, the nutrient solution was recirculated once every $2 \mathrm{~h}$ for $15 \mathrm{~min}$.

\section{Nutrient solution and experiment management}

To prepare the nutrient solution, fertilizer salts were dissolved in the treated domestic effluents according to the recommendations of Furlani et al. (1999) (Tab. 2), with an electrical conductivity (ECsol) of $2.85 \mathrm{dS}$ $\mathrm{m}^{-1}$ and $\mathrm{pH}$ of 6.4 in Experiment I. In Experiment II, the ECsol values were 2.23 and $2.98 \mathrm{dS} \mathrm{m}^{-1}$, and the $\mathrm{pH}$ was 5.8 and 6.2 , respectively for the solutions prepared using tap water and treated domestic effluents. The ECsol and $\mathrm{pH}$ of the solutions were determined using an HI 15321 model conductivity meter and HI 3220 model pH meter (Hanna Instruments Brazil Exp. Imp. Ltda, Barueri, Brazil). During the experiments, the $\mathrm{pH}$ and ECsol values were monitored. When the $\mathrm{pH}$ values were outside the ideal range (between 5.5 and 6.5) for hydroponic cultivation, 


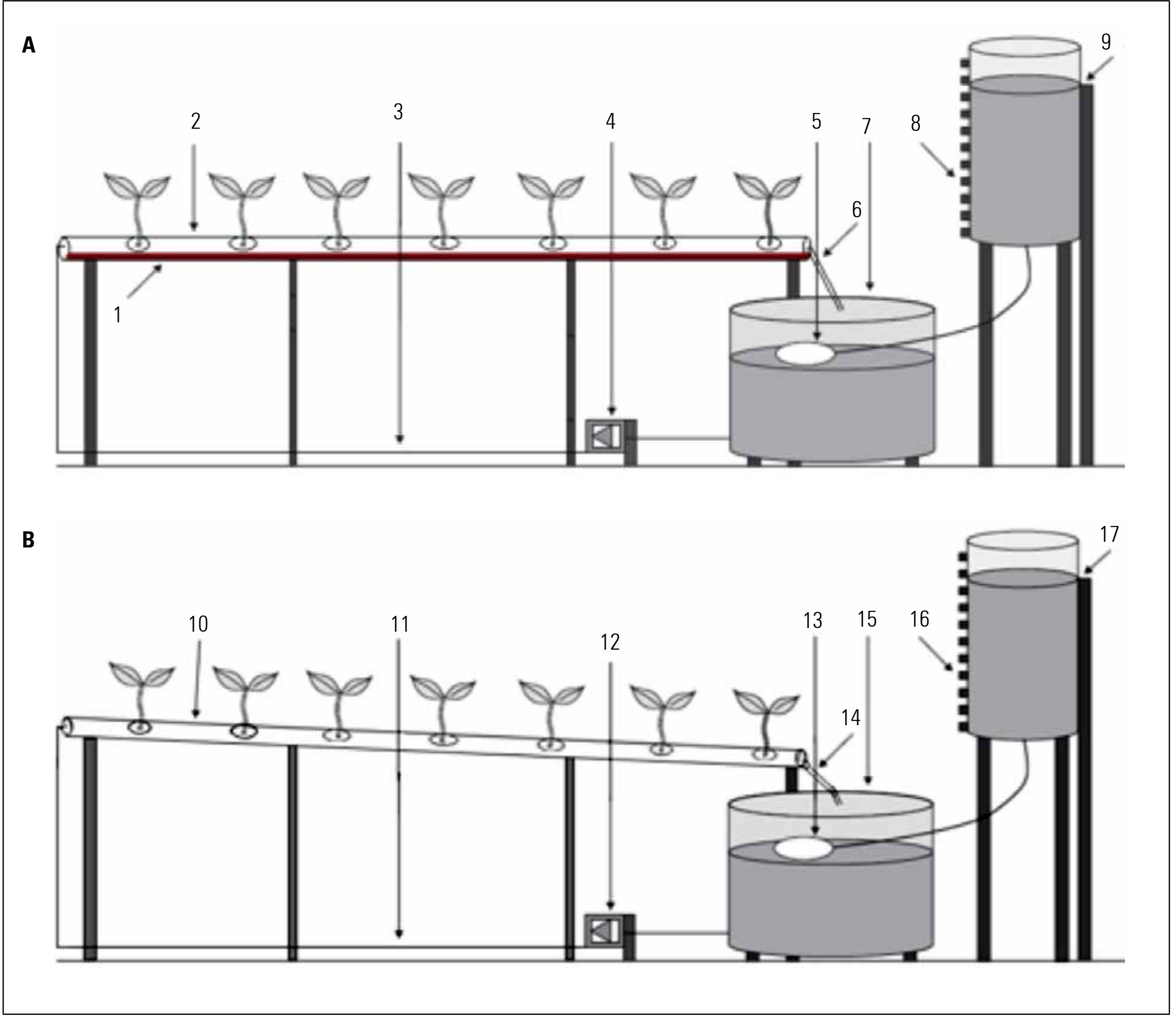

Figure 1. Illustration of the hydroponic systems DFT adapted in PVC tubes (A) and NFT (B) (adapted from Santos et al., 2018). 1. solution depth in hydroponic channel; 2 and 10 . hydroponic channel installed with zero and $3 \%$ slopes, respectively; 3 and 11. PVC tube carrying the solution to the hydroponic channel; 4 and 12. electric pump to inject the solution into the hydroponic channel; 5 and 13. ballcock valve; 6 and 14. conduction of the excess solution to the solution tank; 7 and 15. plastic tank with nutrient solution; 8 and 16. transparent tube with a tape ruler; 9 and 17 . water supply tank.

corrections were made by adding $30 \% \mathrm{HCl}$ or $20 \mathrm{~g}$ $\mathrm{L}^{-1}$ of sodium hydroxide (Vetec Química Fina Ltda, Duque de Caxias, Brazil).

In Experiment I, the recirculation of solution in the cultivation channels in both systems (NFT and DFT) was similar to that used in the nursery (Experiment II). For Experiment II, the solution recirculation used the corresponding interval $(2,4$, or $6 \mathrm{~h})$ with one analog timer for each treatment; each circulation lasted $15 \mathrm{~min}$.
The central part of each hydroponic channel received twelve 30-d old basil seedlings (individually for each genotype), using the nutrient solution at 100\% strength (Furlani et al., 1999) (Tab. 2).

\section{Evaluated variables}

Biomass production. Harvests were carried out at 30 and 35 days after transplanting (DAT) in Experiments I and II, (in each plot) 6 and 12 plants, respectively. The plants were placed in paper bags and dried 
in a Q314M model forced-air oven (Quimis ${ }^{\circledR}$, Diadema, Brazil) at $45^{\circ} \mathrm{C}$ for $10 \mathrm{~d}$ (until constant weight) to quantify the shoot dry biomass (SDB).

Extraction and quantification of essential oil. The essential oil extraction was performed at the Phytochemistry Laboratory of UFRB. The oil was extracted from the leaves, which were separated from the stems after drying. In a $30 \mathrm{~g}$ sample of ground leaf dry biomass (LDB) as previously established by Alves et al. (2015), the oil was extracted with hydrodistillation using a Clevenger apparatus (Clevenger, 1928). The distillation time (2 h) was counted from the moment the first drop of essential oil was deposited in the collector. The final volume of the extracted essential oil was verified in the Clevenger collector. The collected volumes were used to calculate the oil content (OC \%, v/m) (Eq. 1) and oil yield (OY, mL/ plant) (Eq. 2).

$\mathrm{OC}=$ Volume $/[\mathrm{LDB}-(\mathrm{LDB} \times \mathrm{U} / 100)]$

$\mathrm{OY}=(\mathrm{OC} \times \mathrm{LDB}) / 100$

where, $U$ is the moisture content in the LDB sample, obtained after drying at $45^{\circ} \mathrm{C}$.

Chemical composition of essential oil. The chemical composition analysis of the basil essential oil was done at the Chromatography Laboratory of the State University of Southwestern Bahia, Jequié, Brazil. The oil composition was analyzed with gas chromatography, using a Shimadzu GC-2010 gas chromatograph coupled to a Shimadzu MS-OP 2010 mass spectrometer. A DB-5 ms capillary column (5\% phenyl and $95 \%$ dimethylpolysiloxane, $20 \mathrm{~m} \times 0.18 \mathrm{~mm}$ i.d., $0.4 \mu \mathrm{m}$ film thickness) was used, with helium as the carrier gas at a flow rate of $1.8 \mathrm{~mL} \mathrm{~min}^{-1}$. The injector temperature was $220^{\circ} \mathrm{C}$, and the detector temperature was $230^{\circ} \mathrm{C}$. The initial column heating schedule was from $40^{\circ} \mathrm{C}$ (for $2 \mathrm{~min}$ ) to $240^{\circ} \mathrm{C}$ at a rate of $3^{\circ} \mathrm{C} \mathrm{min}^{-1}$.

The constituents were identified by comparing their mass spectra with those of the device database and the NIST 62 database and from the literature (McLafferty and Stauffer, 1989). The analysis of total ion chromatogram was used in the calculation of Kovats indices, obtained by injecting a homologous series of linear hydrocarbons under the same analysis conditions (C4-C24), which was compared to those of Nist and Adams (2007). The relative percentage of the constituents was calculated using the peak area of each substance in the chromatogram.

\section{Statistical analysis}

The data were submitted to analysis of variance with the F-test, and the means were compared with Tukey's test at the 0.05 level of probability.

\section{RESULTS AND DISCUSSION}

\section{Biomass production}

The shoot dry biomass (SDB) of the basil 'Alfavaca Basilicão' and 'Grecco a Palla' were not significantly affected $(P>0.05)$ by the factors studied in Experiment I, with means ranging from 8.6 to $9.1 \mathrm{~g} /$ plant and 7.7 to $9.6 \mathrm{~g} /$ plant, respectively (Tab. 3). For the genotype 'Grecco a Palla' in Experiment II (Tab. 3), the SDB was significantly influenced $(P<0.05)$ by the intervals of the nutrient solution recirculation, with the highest mean $(20.6 \mathrm{~g} /$ plant $)$ obtained under the interval of $2 \mathrm{~h}$, in comparison to the intervals of 4 and $6 \mathrm{~h}$.

The results of present study demonstrate that it is feasible to cultivate the basil genotypes 'Alfavaca Basilicão' and 'Grecco a Palla' at a spacing of $0.20 \mathrm{~m}$ between plants in the NFT or DFT hydroponic system. These results corroborate the findings of Walters (2015), who reported that there was no significant difference in the SDB of basil (Ocimum basilicum L., cv. 'Nufar') with different plant spacings $(0.10,0.15$, $0.20,0.25$, and $0.30 \mathrm{~m}$ ) in the DFT system in basins.

The absence of a significant effect of the types of water on the biomass production of basil genotypes demonstrates that it is technically feasible to use treated domestic effluents to prepare a nutrient solution for cultivation under hydroponic conditions. The absence of a significant effect from the water type may be a consequence of the composition although the treated domestic effluent had nutrients such as $\mathrm{N}$ (21.85 $\left.\mathrm{mg} \mathrm{L}^{-1}\right)$ and $\mathrm{K}\left(29.32 \mathrm{mg} \mathrm{L}^{-1}\right)$ (Tab. 1) but their amounts did not interfere with the basil crop growth, as seen with the nutrient solution of Furlani et al. (1999), and adequately met the nutrient requirements of the plants. In a study on basil grown in pots with peat substrate, Riera-Vila et al. (2019) reported a higher dry biomass yield when plants were irrigated with wastewater, as compared to those irrigated only with public-supply water without nutrients.

In the present study, no evaluations were made for the microbial contamination of the biomass because 
Table 3. Summary of $F$ test of the analysis of variance and mean values of shoot dry biomass (SDB) of the basil genotypes 'Alfavaca Basilicão' (AB) and 'Grecco a Palla' (GP) in Experiment I (hydroponic systems and plant spacings - PS) and Experiment II (types of water and nutrient solution recirculation intervals - IRNS).

\begin{tabular}{|c|c|c|c|c|c|}
\hline Experiment I & \multicolumn{2}{|c|}{ SDB } & \multirow{2}{*}{$\begin{array}{c}\text { Experiment II } \\
\text { Source of variation }\end{array}$} & \multicolumn{2}{|c|}{ SDB } \\
\hline Source of variation & $A B$ & GP & & $A B$ & GP \\
\hline Systems & NS & NS & Type of water & NS & NS \\
\hline PS & NS & NS & IRNS & NS & * \\
\hline Systems x PS & NS & NS & Type of water x IRNS & NS & NS \\
\hline CV (\%) & 31.62 & 21.04 & CV (\%) & 31.62 & 22.09 \\
\hline \multicolumn{6}{|c|}{ Means } \\
\hline \multicolumn{3}{|c|}{ Systems } & \multicolumn{3}{|c|}{ Types of water } \\
\hline DFT & $9.0 \mathrm{a}$ & $8.4 \mathrm{a}$ & Tap water & $13.5 \mathrm{a}$ & $17.7 \mathrm{a}$ \\
\hline NFT & $8.6 \mathrm{a}$ & $8.6 \mathrm{a}$ & Treated domestic effluents & $14.4 \mathrm{a}$ & $15.3 \mathrm{a}$ \\
\hline PS & & & IRNS & & \\
\hline $0.20 \mathrm{~m}$ & $9.1 \mathrm{a}$ & $7.7 \mathrm{a}$ & $2 \mathrm{~h}$ & $16.0 \mathrm{a}$ & $20.6 \mathrm{a}$ \\
\hline $0.30 \mathrm{~m}$ & $8.6 \mathrm{a}$ & $8.3 \mathrm{a}$ & $4 \mathrm{~h}$ & $13.4 \mathrm{a}$ & $14.0 \mathrm{~b}$ \\
\hline $0.40 \mathrm{~m}$ & $8.6 \mathrm{a}$ & $9.6 \mathrm{a}$ & $6 \mathrm{~h}$ & $12.6 \mathrm{a}$ & $14.9 \mathrm{~b}$ \\
\hline
\end{tabular}

Means followed by different letters in the columns for each factor indicate significant differences according to the Tukey's test $(P \leq 0.05) ;{ }^{*}$ significant at $(P \leq 0.05)$ and ${ }^{\text {NS }}$ - not significant according to the F-test; CV - coefficient of variation.

Cuba et al. (2015) indicated that there were no such risks in lettuce cultivated hydroponically using treated domestic effluents.

\section{Basil essential oil content and yield}

In Experiment I, there was a significant interaction $(P<0.05)$ between the factors only for essential oil content (OC) of genotype 'Grecco a Palla' (Tab. 4). For Experiment II (Tab. 5), the essential oil yield (OY) was significantly influenced $(P<0.05)$ by the nutrient solution recirculation intervals for genotype 'Grecco a Palla'.

For the oil content of genotype 'Alfavaca Basilicão' in Experiment I (Tab. 4), the mean values were between 1.70 and $1.83 \%$, regardless of the plant spacing in the cultivation channels and the hydroponic systems. For genotype 'Grecco a Palla', in the analysis of the interaction between plant spacing in the cultivation channels and the hydroponic systems, the highest plant density (spacing of $0.20 \mathrm{~m}$ between plants) in the DFT system led to a higher oil content $(1.98 \%)$ than in the NFT system (1.52\%). With the $0.30 \mathrm{~m}$ plant spacing, there was a higher oil content when the plants were cultivated in the NFT system $(1.92 \%)$ than in the DFT system (1.40\%). The largest spacing $(0.40 \mathrm{~m})$ had no significant differences
$(P>0.05)$ between the means obtained in the NFT and DFT systems, varying between 1.75 and $1.81 \%$. When the hydroponic systems were analyzed individually, only DFT had a significant difference between the means as function of the plant spacing, with the lowest oil content observed in the $0.30 \mathrm{~m}$ spacing.

Based on the results, there were variations in the oil contents as a function of the basil genotypes according to the spacing used between plants. This type of behavior has been observed in other studies under field conditions, such as Daneshian et al. (2011), who studied two basil genotypes under three plant densities. Alemu et al. (2018) reported the highest mean oil content for genotype 'BO-1' at the smallest spacing between plants $(0.20 \mathrm{~m})$, whereas two other genotypes ('BO-4' and 'BO-5') with various plant spacings $(0.20,0.30$ and $0.40 \mathrm{~m})$ did not influence the oil content, and, in general, the mean oil content did not exceed $1 \%$.

For Experiment II, the oil contents ranged between 1.53 and $1.67 \%$ for genotype 'Alfavaca Basilicão' and between 1.61 and $1.82 \%$ for genotype 'Grecco a Palla', regardless of the type of water used and the nutrient solution recirculation intervals (Tab. 5). These values are within the same range observed in Experiment I (Tab. 4). 
Table 4. Summary of $F$ test of the analysis of variance and mean values for essential oil content (OC) and yield (OY) of basil genotypes 'Alfavaca Basilicão' and 'Grecco a Palla' with different plant spacing (PS) in the hydroponic channels of the NFT and DFT systems in Experiment $I$.

\begin{tabular}{|c|c|c|c|c|c|c|}
\hline \multirow{2}{*}{ Source of variation } & \multicolumn{2}{|c|}{ 'Alfavaca Basilicão' } & \multicolumn{4}{|c|}{ 'Grecco a Palla' } \\
\hline & OC & OY & OY & \multicolumn{3}{|c|}{$\mathrm{OC}$} \\
\hline Systems & NS & NS & NS & \multicolumn{3}{|c|}{ NS } \\
\hline PS & NS & NS & NS & \multicolumn{3}{|c|}{ NS } \\
\hline Systems x PS & NS & NS & NS & \multicolumn{3}{|c|}{$*$} \\
\hline CV (\%) & 11.30 & 23.96 & 23.26 & \multicolumn{3}{|c|}{14.29} \\
\hline \multicolumn{7}{|c|}{ Means } \\
\hline \multirow{3}{*}{ Systems } & \multirow{3}{*}{$\begin{array}{l}O C \\
(\%)\end{array}$} & \multirow{3}{*}{\multicolumn{2}{|c|}{$\begin{array}{c}\text { OY } \\
\text { (mL/plant) }\end{array}$}} & \multicolumn{3}{|c|}{ OC (\%) } \\
\hline & & & & \multicolumn{3}{|c|}{ PS } \\
\hline & & & & $0.20(\mathrm{~m})$ & $0.30(\mathrm{~m})$ & $0.40(\mathrm{~m})$ \\
\hline DFT & $1.64 \mathrm{a}$ & $0.104 \mathrm{a}$ & $0.102 \mathrm{a}$ & $1.98 \mathrm{aA}$ & $1.40 \mathrm{bB}$ & $1.81 \mathrm{aAB}$ \\
\hline NFT & $1.83 \mathrm{a}$ & $0.115 a$ & $0.109 a$ & $1.52 \mathrm{bA}$ & $1.92 \mathrm{aA}$ & $1.75 \mathrm{aA}$ \\
\hline \multicolumn{7}{|l|}{ PS } \\
\hline $0.20 \mathrm{~m}$ & $1.76 \mathrm{a}$ & $0.112 \mathrm{a}$ & $0.097 \mathrm{a}$ & & & \\
\hline $0.30 \mathrm{~m}$ & $1.76 \mathrm{a}$ & $0.113 a$ & $0.097 \mathrm{a}$ & & & \\
\hline $0.40 \mathrm{~m}$ & $1.70 \mathrm{a}$ & $0.104 \mathrm{a}$ & $0.122 \mathrm{a}$ & & & \\
\hline
\end{tabular}

Means followed by lowercase letters in the columns indicate significant differences; for $\mathrm{OC}$ of genotype 'Grecco a Palla', lowercase letters in the columns compare the means of the hydroponic systems in each plant spacing, and uppercase letters in the rows compare the means of the plant spacing in each hydroponic system, according to the Tukey's test $(P \leq 0.05)$; ${ }^{*}$ significant at $(P \leq 0.05)$ and ${ }^{N S}$ - not significant according to the F-test; $C V$ - coefficient of variation.

Table 5. Summary of $F$ test of the analysis of variance and mean values for essential oil content (OC) and yield (OY) of basil genotypes 'Alfavaca Basilicão' and 'Grecco a Palla' using tap water (TW) and treated domestic effluents (TDE) with different nutrient solution recirculation intervals (IRNS) in the DFT hydroponic system in Experiment II.

\begin{tabular}{|c|c|c|c|c|}
\hline \multirow{2}{*}{ Source of variation } & \multicolumn{2}{|c|}{ 'Alfavaca Basilicão' } & \multicolumn{2}{|c|}{ 'Grecco a Palla' } \\
\hline & OC & OY & $\mathrm{OC}$ & OY \\
\hline Types of water & NS & NS & NS & NS \\
\hline IRSN & NS & NS & NS & $*$ \\
\hline Types of water $x$ IRSN & NS & NS & NS & NS \\
\hline CV (\%) & 16.59 & 37.89 & 14.88 & 27.22 \\
\hline \multicolumn{5}{|c|}{ Means } \\
\hline Types of water & $\begin{array}{l}\mathrm{OC} \\
(\%)\end{array}$ & $\begin{array}{c}\text { OY } \\
\text { (mL/plant) }\end{array}$ & $\begin{array}{l}\mathrm{OC} \\
(\%)\end{array}$ & $\begin{array}{c}\text { OY } \\
\text { (mL/plant) }\end{array}$ \\
\hline TW & $1.54 \mathrm{a}$ & $0.137 a$ & $1.61 \mathrm{a}$ & $0.159 a$ \\
\hline TDE & $1.65 \mathrm{a}$ & $0.153 a$ & $1.81 \mathrm{a}$ & $0.165 a$ \\
\hline \multicolumn{5}{|l|}{ IRNS } \\
\hline $2 \mathrm{~h}$ & $1.58 \mathrm{a}$ & $0.168 \mathrm{a}$ & $1.82 \mathrm{a}$ & $0.207 a$ \\
\hline $4 \mathrm{~h}$ & $1.53 \mathrm{a}$ & $0.129 a$ & $1.61 \mathrm{a}$ & $0.127 b$ \\
\hline $6 \mathrm{~h}$ & $1.67 \mathrm{a}$ & $0.138 a$ & $1.70 \mathrm{a}$ & $0.151 \mathrm{ab}$ \\
\hline
\end{tabular}

Means followed by lowercase letters in the columns for each factor indicate significant differences according to the Tukey's test $(P \leq 0.05)$; ${ }^{*}$ significant at $(P \leq 0.05)$ and ${ }^{N S}$ - not significant according to the F-test; CV - coefficient of variation. 
For oil yield in Experiment I, regardless of the spacing between plants and hydroponic systems, the mean values varied between 0.104 and $0.115 \mathrm{~mL} /$ plant for genotype 'Alfavaca Basilicão' and between 0.097 to $0.122 \mathrm{~mL} /$ plant for genotype 'Grecco a Palla' (Tab 4).

For Experiment II (Tab. 5), the mean oil yield of genotype 'Alfavaca Basilicão' was between 0.129 and 0.168 $\mathrm{mL} /$ plant. For genotype 'Grecco a Palla', the highest oil yield $(0.207 \mathrm{~mL} /$ plant $)$ was recorded with the interval of $2 \mathrm{~h}$.

\section{Essential oil composition}

In Experiment I (Tab. 6), 10 constituents were identified in the basil essential oil, namely: eucalyptol, linalool, methyl eugenol, trans- $\alpha$-bergamotene, $\gamma$-cadinene, $\alpha$-copaene, delta-guaiene, terpine-4-ol, $\beta$-elemene, and methyl cinnamate. Of the 10 constituents found in Experiment I, only methyl cinnamate was not found in Experiment II (Tab. 7). Some constituents were only found in some treatments, and, as a result, the statistical analysis only considered five main constituents: eucalyptol, linalool, trans- $\alpha$-bergamotene, $\gamma$-cadinene and $\alpha$-copaene for
Experiment I; and eucalyptol, linalool, methyl eugenol (except for the genotype 'Alfavaca Basilicão'), trans- $\alpha$-bergamotene and $\gamma$-cadinene for Experiment II.

The five constituents of the oil evaluated in Experiment I (Tab. 6) were significantly influenced by the interaction between the factors in both basil genotypes. For Experiment II (Tab. 7), a significant interaction and single effects from the factors occurred for all constituents, except linalool (genotype 'Alfavaca Basilicão'), trans- $\alpha$-bergamotene and methyl eugenol (genotype 'Grecco a Palla').

In Experiment I (Tab. 6), genotype 'Alfavaca Basilicão' had a higher percentage of linalool $(70.10 \%)$ in the DFT system with the spacing of $0.40 \mathrm{~m}$, while the NFT system had the highest percentage of linalool $(63.81 \%)$ at the smallest spacing $(0.20 \mathrm{~m})$. For genotype 'Grecco a Palla', the NFT and DFT systems had the highest percentages of linalool, 43.03 and $33.37 \%$, respectively, at the spacings of 0.30 and $0.40 \mathrm{~m}$.

According to the literature, the chemical composition of basil essential oil is quite complex (Daryadar, 2017). In the present study, the chemical composition of the

Table 6. Summary of $F$ test of the analysis of variance and mean values of the follow-up analyses of the interactions between plant spacing in the hydroponic channels and systems using treated domestic effluents for essential oil compounds $(\%)$ of the basil genotypes 'Alfavaca Basilicão' and 'Grecco a Palla' in Experiment I.

\begin{tabular}{|c|c|c|c|c|c|c|c|c|c|c|}
\hline \multirow{3}{*}{\begin{tabular}{|l|} 
Source of variation \\
Systems (A) \\
Plant spacings (B) \\
\end{tabular}} & \multirow{2}{*}{\multicolumn{3}{|c|}{ F test }} & \multirow[b]{3}{*}{ CV $(\%)$} & \multirow{2}{*}{\multicolumn{3}{|c|}{ DFT }} & \multirow{2}{*}{\multicolumn{3}{|c|}{ NFT }} \\
\hline & & & & & & & & & & \\
\hline & $A$ & $B$ & $A \times B$ & & $0.20 \mathrm{~m}$ & $0.30 \mathrm{~m}$ & $0.40 \mathrm{~m}$ & $0.20 \mathrm{~m}$ & $0.30 \mathrm{~m}$ & $0.40 \mathrm{~m}$ \\
\hline \multicolumn{11}{|c|}{ 'Alfavaca Basilicão' } \\
\hline Linalool & $* *$ & $* *$ & $* *$ & 4.26 & $52.38 \mathrm{bB}$ & $56.26 \mathrm{aB}$ & $70.10 \mathrm{aA}$ & $63.81 \mathrm{aA}$ & $47.00 \mathrm{bC}$ & $53.20 \mathrm{bB}$ \\
\hline Trans- $\alpha$-bergamotene & $* *$ & $*$ & $* *$ & 10.52 & $16.74 \mathrm{aB}$ & $20.74 \mathrm{aA}$ & $12.18 \mathrm{aC}$ & $11.50 \mathrm{bAB}$ & $11.00 \mathrm{bB}$ & $14.37 \mathrm{aA}$ \\
\hline Eucaliptol & NS & $* *$ & $* *$ & 7.12 & $16.09 \mathrm{bA}$ & $15.46 \mathrm{aA}$ & $13.76 \mathrm{aA}$ & $19.00 \mathrm{aA}$ & $11.50 \mathrm{bC}$ & $14.54 \mathrm{aB}$ \\
\hline$\gamma$-cadinene & $* *$ & ** & ** & 4.05 & $4.13 \mathrm{bA}$ & $4.08 \mathrm{aA}$ & $3.65 \mathrm{bB}$ & 5.54 aA & $3.00 \mathrm{bC}$ & $4.51 \mathrm{aB}$ \\
\hline$\alpha$-copaene & $* *$ & ** & ** & 4.76 & $0.00 \mathrm{bA}$ & $0.00 \mathrm{bA}$ & $0.00 \mathrm{bA}$ & $5.54 \mathrm{aA}$ & $3.00 \mathrm{aB}$ & $1.49 \mathrm{aC}$ \\
\hline \multicolumn{11}{|c|}{ 'Grecco a Palla' } \\
\hline Linalool & $* *$ & * & ** & 22.58 & $19.54 \mathrm{aB}$ & $10.19 \mathrm{bB}$ & $33.37 \mathrm{aA}$ & $23.22 \mathrm{aB}$ & $43.03 \mathrm{aA}$ & $28.74 \mathrm{aB}$ \\
\hline Trans- $\alpha$-bergamotene & $* *$ & $*$ & $* *$ & 25.39 & $35.03 \mathrm{aB}$ & $58.15 \mathrm{aA}$ & $19.74 \mathrm{aB}$ & $23.92 \mathrm{aA}$ & $16.06 \mathrm{bA}$ & $24.06 \mathrm{aA}$ \\
\hline Eucaliptol & NS & NS & * & 25.38 & $3.98 \mathrm{aB}$ & $3.33 \mathrm{aB}$ & $6.81 \mathrm{aA}$ & $4.58 \mathrm{aA}$ & $4.18 \mathrm{aA}$ & $3.55 \mathrm{bA}$ \\
\hline$\gamma$-cadinene & $* *$ & $*$ & $* *$ & 11.65 & $7.55 \mathrm{aB}$ & $10.58 \mathrm{aA}$ & $5.42 \mathrm{bC}$ & $6.28 \mathrm{aAB}$ & $4.79 \mathrm{bB}$ & $7.59 \mathrm{aA}$ \\
\hline$\alpha$-copaene & $* *$ & ** & *** & 12.32 & $9.53 \mathrm{aA}$ & $0.00 \mathrm{bC}$ & $4.43 \mathrm{bB}$ & $6.57 \mathrm{bB}$ & $5.72 \mathrm{aB}$ & $11.30 \mathrm{aA}$ \\
\hline
\end{tabular}

In the rows, the lowercase letters compare the means of respective plant spacing between hydroponic systems, and uppercase letters compare the means of the plant spacing in the respective hydroponic systems according to Tukey's test at $(P \leq 0.05) ;{ }^{*}$ and ${ }^{* *}$ significant at $P \leq 0.05$ and $P \leq 0.01$, respectively, and ${ }^{\text {NS }}$ - not significant according to the F-test; CV - coefficient of variation. 
Table 7. Summary of $F$ test of the analysis of variance and mean values of the follow-up analyses of the interaction between types of water and nutrient solution recirculation intervals (IRNS) for essential oil compounds (\%) of the basil genotypes 'Alfavaca Basilicão' and 'Grecco a Palla' in Experiment II.

\begin{tabular}{|c|c|c|c|c|c|c|c|c|c|c|}
\hline \multirow{3}{*}{$\begin{array}{l}\text { Source of variation } \\
\text { Types of water (A) } \\
\text { IRNS (B) } \\
\end{array}$} & \multirow{2}{*}{\multicolumn{3}{|c|}{ F test }} & \multirow[b]{3}{*}{ CV (\%) } & \multirow{2}{*}{\multicolumn{3}{|c|}{ Tap water }} & \multirow{2}{*}{\multicolumn{3}{|c|}{ Treated domestic effluents }} \\
\hline & & & & & & & & & & \\
\hline & A & B & $A \times B$ & & $2 \mathrm{~h}$ & $4 \mathrm{~h}$ & $6 \mathrm{~h}$ & $2 \mathrm{~h}$ & $4 \mathrm{~h}$ & $6 \mathrm{~h}$ \\
\hline \multicolumn{11}{|c|}{ 'Alfavaca Basilicão' } \\
\hline Linalool & NS & NS & NS & 5.47 & $63.64 \mathrm{aA}$ & $59.84 \mathrm{aA}$ & $59.47 \mathrm{aA}$ & $62.88 \mathrm{aA}$ & $58.27 \mathrm{aA}$ & $61.67 \mathrm{aA}$ \\
\hline Trans- $\alpha$-bergamottin & $* *$ & $*$ & * & 11.93 & $14.75 \mathrm{aAB}$ & $19.15 \mathrm{aA}$ & $13.91 \mathrm{bB}$ & $15.98 \mathrm{aB}$ & $20.10 \mathrm{aAB}$ & $22.49 \mathrm{aA}$ \\
\hline Eucaliptol & $* *$ & NS & $* *$ & 5.35 & $9.96 \mathrm{bC}$ & $14.12 \mathrm{aB}$ & $18.40 \mathrm{aA}$ & $13.18 \mathrm{aA}$ & $9.36 \mathrm{bB}$ & $6.55 \mathrm{bC}$ \\
\hline $\boldsymbol{\gamma}$-cadinene & NS & $* *$ & * & 4.51 & $4.44 \mathrm{aB}$ & $5.06 \mathrm{bA}$ & $5.49 \mathrm{aA}$ & $4.45 \mathrm{aB}$ & $5.66 \mathrm{aA}$ & $5.28 \mathrm{aA}$ \\
\hline \multicolumn{11}{|c|}{ 'Grecco a Palla' } \\
\hline Linalool & NS & NS & * & 28.93 & $43.27 \mathrm{aA}$ & 19.94 bB & $53.37 \mathrm{aA}$ & $24.96 \mathrm{bA}$ & $33.15 \mathrm{aA}$ & $28.47 \mathrm{bA}$ \\
\hline Trans- $\alpha$-bergamotene & NS & NS & NS & 21.03 & $20.48 \mathrm{aA}$ & $15.85 \mathrm{aA}$ & $15.50 \mathrm{aA}$ & $19.59 \mathrm{aA}$ & $16.85 \mathrm{aA}$ & $18.76 \mathrm{aA}$ \\
\hline Eucaliptol & $* *$ & $*$ & $* *$ & 36.30 & $8.49 \mathrm{aA}$ & 3.23 bB & $11.50 \mathrm{aA}$ & $0.00 \mathrm{bB}$ & $7.42 \mathrm{aA}$ & $4.67 \mathrm{bA}$ \\
\hline Methyl eugenol & NS & NS & NS & 42.83 & $7.93 \mathrm{aA}$ & $14.43 \mathrm{aA}$ & 9.76 aA & $11.01 \mathrm{aA}$ & $15.96 \mathrm{aA}$ & $20.32 \mathrm{aA}$ \\
\hline$\gamma$-cadinene & $* *$ & $* *$ & $* *$ & 8.84 & 6.56 aA & $4.77 \mathrm{aB}$ & $4.07 \mathrm{bB}$ & $0.00 \mathrm{bC}$ & $4.52 \mathrm{aB}$ & $7.16 \mathrm{aA}$ \\
\hline
\end{tabular}

In the rows, the lowercase letters compare the means of the respective recirculation intervals of the nutrient solution between types of water, and uppercase letters compare the means of the recirculation intervals of the nutrient solution in the respective type of water according to Tukey's test at $(P \leq 0.05) ;{ }^{*}$ and ${ }^{* *}$ significant at $P \leq 0.05$ and $P \leq 0.01$, respectively, and ${ }^{N S}$ - not significant according to F-test; $C V$ - coefficient of variation.

oil varied because of the genotypic differences of the basil, which partially explained the results. A complementary explanation of these differences (plant spacing in the channels of hydroponic systems) may be related to the inter or intraspecific competition of plants for light, air, water and nutrients (Maboko and Du Plooy, 2013; Skrypnik et al., 2019), modifying the assimilation capacity and, therefore, the secondary metabolism in favor of biosynthesis and the accumulation of different volatile compounds (Hassanpouraghdam et al., 2010; Ciriello et al., 2020).

In the study conducted by Arabaci and Bayram (2004) on basil cultivation in soil, linalool was the major constituent, varying according to the spacing used from one cycle to the other; in the first cycle, the highest percentage $(76.46 \%)$ was obtained at a spacing of $0.20 \mathrm{~m}$ between plants under nitrogen applications, while, in the second and third cycles, the highest percentages (70.47 and $71.43 \%$, respectively) were obtained at a spacing of $0.40 \mathrm{~m}$ without nitrogen applications.

For Experiment II (Tab. 7), regardless of the type of water and the nutrient solution recirculation intervals, the percentages of linalool varied between 58.27 and $63.64 \%$ for genotype 'Alfavaca Basilicão'. For 'Grecco a Palla', there was no significant difference between the means of linalool percentages as a function of the recirculation interval using domestic effluent, ranging from 24.96 to $33.15 \%$; however, when tap water was used to prepare the nutrient solution, the linalool percentages were higher with the intervals of 2 and 6 h, 43.27 and $53.37 \%$, respectively.

\section{CONCLUSIONS}

It is technically feasible to use treated domestic effluents to prepare nutrient solutions for the hydroponic cultivation of basil. In general, the shoot dry biomass and the oil content and yield of both basil genotypes were not influenced by the hydroponic systems (NFT or DFT), plant spacing $(0.20,0.30$, and $0.40 \mathrm{~m})$, or type of water (tap water or treated domestic effluents). The genotypes showed a mean oil content between 1.6 and $1.7 \%$. Genotype 'Grecco a Palla' was more sensitive to the nutrient solution recirculation intervals, and higher means of biomass production and essential oil content were observed with the interval of $2 \mathrm{~h}$. Linalool was the major constituent in the essential oil in the two basil genotypes. 


\section{ACKNOWLEDGMENTS}

The authors thank the Bahia State Research Support Foundation (FAPESB) for granting the Doctoral scholarship to the first author, the Coordination for the Improvement of Higher Education Personnel (CAPES), and the National Council for Scientific and Technological Development (CNPq) for their support. Special thanks to Professor Franceli da Silva of Federal University of Recôncavo of Bahia for help in the analysis and interpretation of constituents of basil oil through the Chromatography Laboratory of the State University of Southwestern Bahia, Jequié, Brazil.

Conflict of interests: The manuscript was prepared and reviewed with the participation of the all authors, who declare that there exists no conflict of interest that puts at risk the validity of the presented results.

\section{BIBLIOGRAPHIC REFERENCES}

Adams, R.P. 2007. Identification of essential oil components by gas chromatograpy/mass spectroscopy. $4^{\text {th }}$ ed. Allured Publishing Corporation, Carol Stream, IL.

Alemu, A., W. Garedew, and A. Gebre. 2018. Essential oil yield and yield components of basil (Ocimum basilicum L.) as affected by genotype and intrarow spacing at Jimma, SW Ethiopia. Acta Agrobot. 71(3), 1743. Doi: 10.5586/aa. 1743

Alves, L.S., H.R. Gheyi, V.P.S. Paz, A.N. Santos, M.G. Silva, and S.S. Bandeira. 2019. Cultivo de manjericão utilizando efluente doméstico tratado em sistemas hidropônicos sob diferentes espaçamentos entre plantas. Irriga 24(3), 460-472. Doi: 10.15809/ irriga.2019v24n3p460-472

Alves, L.S., V.P.S. Paz, A.J.P. Silva, G.X.S. Oliveira, F.E.R. Oliveira, and E.L. Amorim. 2015. Teor, rendimento e composição química do óleo essencial de plantas de manjericão submetidas ao estresse salino com NaCl. Rev. Bras. Plantas Med. 17(4), 807-813. Doi: 10.1590/1983-084X/14_031

Arabaci, O. and E. Bayram. 2004. The effect of nitrogen fertilization and different plant densities on some agronomic and technologic characteristic of Ocimum basilicum L. (basil). J. Agron. 3(4), 255-262. Doi: 10.3923/ja.2004.255.262

Azevedo Neto, A.D., R.V. Menezes, H.R. Gheyi, P.C.C. Silva, A.M.W. Cova, R.F. Ribas, and M.O. Ribeiro. 2019. Salt-induced changes in solutes, pigments and essential oil of two basil (Ocimum basilicum L.) genotypes under hydroponic cultivation. Aust. J. Crop Sci. 13(11), 1856-1864. Doi: 10.21475/ajcs.19.13.11.p2015
Bione, M.A.A., V.P.S. Paz, F. Silva, R.F. Ribas, and T.M. Soares. 2014. Crescimento e produção de manjericão em sistema hidropônico NFT sob salinidade. Rev. Bras. Eng. Agríc. Ambient. 18(12), 1228-1234. Doi: 10.1590/1807-1929/agriambi.v18n12p1228-1234

Cifuentes-Torres, L., L.G. Mendoza-Espinosa, G. Correa-Reyes, and L.W. Daesslé. 2020. Hydroponics with wastewater: a review of trends and opportunities. Water Environ. J. 35(1), 166-180. Doi: 10.1111/wej.12617

Ciriello, M., A. Pannico, C. El-Nakhel, L. Formisano, F. Cristofano, L.G. Duri, F. Pizzolongo, R. Romano, S. De Pascale, G. Colla, M. Cardarelli, and Y. Rouphael. 2020. Sweet basil functional quality as shaped by genotype and macronutrient concentration reciprocal action. Plants 9, 1786. Doi: 10.3390/plants9121786

Clevenger, J.F. 1928. Apparatus for the determination of volatile oil. J. Am. Pharm. Assoc. 17(4), 345-349. Doi: 10.1002/jps.3080170407

Cova, A.M.W., F.T.O. Freitas, P.C. Viana, M.R.S. Rafael, A.D. Azevedo Neto, and T.M. Soares. 2017. Content of inorganic solutes in lettuce grown with brackish water in different hydroponic systems. Rev. Bras. Eng. Agríc. Ambient. 21(3), 150-155. Doi: 10.1590/18071929/agriambi.v21n3p150-155

Cuba, R.S., J.R. Carmo, C.F. Souza, and R.G. Bastos. 2015. Potencial de efluente de esgoto doméstico tratado como fonte de água e nutrientes no cultivo hidropônico de alface. Rev. Ambient. Água 10(3), 574-586. Doi: 10.4136/ambi-agua. 1575

Daneshian, J., M. Yousef, P. Zandi, P. Jonoubi, and L. Khatibani. 2011. Effect of planting density and cattle manure on some qualitative and quantitative traits in two basil varieties under Guilan condition, Iran. Am. Eurasian J. Agric. Environ. Sci. 11(1), 95-103.

Daryadar, M. 2017. Comparative description of essential oil quantitative and qualitative indexes during the growth and development of sweet basil in conditions of the newest water-stream hydroponics. J. Civil Environ. Eng. 7(2), 1000271. Doi: 10.4172/2165-784X.1000271

Egbuikwem, P.N., J.C. Mierzwa, and D.P. Saroj. 2020. Assessment of suspended growth biological process for treatment and reuse of mixed wastewater for irrigation of edible crops under hydroponic conditions. Agric. Water Manag. 231, 106034. Doi: 10.1016/j. agwat.2020.106034

Fuentes-Castañeda, O., M.L. Domínguez-Patiño, J. Domínguez-Patiño, R.M. Melgoza-Alemán, and O.G. Villegas-Torres. 2016. Effect of electric field on the kinetics of growth of lettuce (Lactuca sativa) in a hydroponic system. J. Agric. Chem. Environ. 5(3), 113-120. Doi: 10.4236/jacen.2016.53013

Furlani, P.R., L.C.P. Silveira, D. Bolonhezi, and V. Faquin. 1999. Cultivo hidropônico de plantas. IAC, Campinas, Brazil. 
Gonçalves, K.S., L.S. Alves, V.P.S. Paz, and S.S. Bandeira. 2019. Chlorophyll fluorescence of basil plants cultivated in a hydroponic system using treated domestic wastewater. Eng. Agríc. 39(3), 288-293. Doi: 10.1590/1809-4430-eng.agric.v39n3p288-293/2019

Gondim Filho, H., P.C.C. Silva, M.G. Silva, M.M. Pereira, T.M. Soares, A.D. Azevedo Neto, R.S. Vasconcelos, and H.R. Gheyi. 2018. Growth, production and essential oil content of basil genotypes in hydroponic conditions under salt stress. J. Exp. Agric. Int. 25(1), 1-10. Doi: 10.9734/JEAI/2018/43023

Hassanpouraghdam, M.B., G.R. Gohari, S.J. Tabatabaei, and M.R. Dadpour. 2010. Inflorescence and leaves essential oil composition of hydroponically grown Ocimum basilicum L. J. Serb. Chem. Soc. 75(10), 13611368. Doi: 10.2298/JSC100311113H

Heidari, M. 2012. Effects of salinity stress on growth, chlorophyll content and osmotic components of two basil (Ocimum basilicum L.) genotypes. Afr. J. Biotechnol. 11(2), 379-384. Doi: 10.5897/AJB11.2572

Maboko, M.M. and C.P. Du Plooy. 2013. High-plant density planting of basil (Ocimum basilicum) during summer/ fall growth season improves yield in a closed hydroponic system. Acta Agric. Scand. B Soil Plant Sci. 63(8), 748-752. Doi: 10.1080/09064710.2013.861921

McLafferty, F.W. and D. Stauffer. 1989. Registry of spectral data. John Wiley \& Sons, New York, NY.

Riera-Vila, I., N.O. Anderson, C.F. Hodge, and M. Rogers. 2019. Anaerobically-digested brewery wastewater as a nutrient solution for substrate-based food production. Horticulturae 5(2), 43. Doi: 10.3390/ horticulturae 5020043

Saha, S., A. Monroe, and M.R. Day. 2016. Growth, yield, plant quality and nutrition of basil (Ocimum basilicum L.) under soilless agricultural systems. Ann. Agric. Sci. 61(2), 181-186. Doi: 10.1016/j.aoas.2016.10.001

Santos, A.C., M.G. Silva, C.L. Boechat, D.S. Chagas, and W.S. Mendes. 2018. Brackish water: an option for producing hydroponic Capsicum annuum in laminar flows of mineral nutrients. Rev. Colomb. Cienc. Hortic. 12(1), 147-155. Doi: 10.17584/rcch.2018v12i1.7446

Santos, J.F., M.A. Coelho Filho, J.L. Cruz, T.M. Soares, and A.M.L. Cruz. 2019. Growth, water consumption and basil production in the hydroponic system under salinity. Rev. Ceres 66(1), 45-53. Doi: 10.1590/0034-737x201966010007

Santos Júnior, J.A., H.R. Gheyi, A.R. Cavalcante, S.S. Medeiros, N.S. Dias, and D.B. Santos. 2015. Water use efficiency of coriander produced in a low-cost hydroponic system. Rev. Bras. Eng. Agríc. Ambient. 19(12), 1152-1158. Doi: 10.1590/1807-1929/agriambi. v19n12p1152-1158

Silva, H.H.B., A.D. Azevedo Neto, R.V. Menezes, P.C.C. Silva, and H.R. Gheyi. 2019. Use of hydrogen peroxide in acclimation of basil (Ocimum basilicum L.) to salt stress. Turk. J. Bot. 43(2), 208-217. Doi: 10.3906/bot-1807-80

Silva, M.G., L.S. Alves, T.M. Soares, H.R. Gheyi, and M.A.A. Bione. 2020b. Growth, production and water use efficiency of chicory (Cichorium endivia L.) in hydroponic systems using brackish waters. Adv. Hortic. Sci. 34(3), 243-253. Doi: 10.13128/ahsc-8855

Silva, M.G., I.S. Oliveira, T.M. Soares, H.R. Gheyi, G.O. Santana, and J.S. Pinho. 2018. Growth, production and water consumption of coriander in hydroponic system using brackish waters. Rev. Bras. Eng. Agríc. Ambient. 22(8), 547-552. Doi: 10.1590/1807-1929/ agriambi.v22n8p547-552

Silva, M.G., T.M. Soares, H.R. Gheyi, I.P. Costa, and R.S. Vasconcelos. 2020a. Growth, production and water consumption of coriander grown under different recirculation intervals and nutrient solution depths in hydroponic channels. Emir. J. Food Agric. 32(4), 281294. Doi: 10.9755/ejfa.2020.v32.i4.2094

Silva, M.G., T.M. Soares, H.R. Gheyi, I.S. Oliveira, J.A. Silva Filho, and F.F. Carmo. 2016. Frequency of recirculation of the nutrient solution in the hydroponic cultivation of coriander with brackish water. Rev. Bras. Eng. Agríc. Ambient. 20(5), 447-454. Doi: 10.1590/18071929/agriambi.v20n5p447-454

Skrypnik, L., A. Novikova, and E. Tokupova. 2019. Improvement of phenolic compounds, essential oil content and antioxidant properties of sweet basil (Ocimum basilicum L.) depending on type and concentration of selenium application. Plants 8, 458. Doi: 10.3390/ plants8110458

Veloso, R.A., H.G. Castro, L.C.A. Barbosa, D.P. Cardoso, A.F. Chagas Júnior, and G.N. Scheidt. 2014. Teor e composição do óleo essencial de quatro acessos e duas cultivares de manjericão (Ocimum basilicum L.). Rev. Bras. Plantas Med. 16(2), 364-371. Doi: 10.1590/1983-084X/12_180

Walters, K.J. 2015. Quantifying the effects of hydroponic systems, nutrient solution, and air temperature on growth and development of basil (Ocimum L.) species. MSc thesis. Iowa State University, Ames, IA.

Walters, K.J. and C.J. Currey. 2015. Hydroponic greenhouse basil production: Comparing systems and cultivars. Hort Technology 25(5), 645-650. Doi: 10.21273/ HORTTECH.25.5.645 